\title{
Analisis beta karoten dari ekstrak jonjot buah labu kuning (Cucurbita moschata)
}

\section{Dokri Gumolung}

Ilmu Kimia FMIPA, Universitas Negeri Manado, Tondano, 95619, Indonesia

\section{INFO ARTIKEL}

Diterima 25 Mei 2017

Disetujui 29 Juni 2017

\section{Key word:}

Yellow Pumpkin strands,

Beta carotene,

Petroleum Ether Extraction,

Ethanol Extraction

\section{Kata kunci:}

Jonjot Labu kuning,

Betakaroten,

Ekstraksi Petroleum Ether,

Ekstraksi Etanol
${ }^{*}$ e-mail:

dokrigumolung@unima.ac.id

*Telp:

085396672121

\begin{abstract}
A B S T R A C T
The purpose of this study was to identify compounds such as beta carotene, such as rubber extracts from various pumpkin strands extracts. Pumpkin plant as a minor food commodity, it is very rich in bioactive compounds that act as antioxidant very useful for human health. Strands in yellow fruit processing is often used as waste. This research was conducted by using laboratory analysis method through the following stages, determination and sampling, sample preparation, content analysis of beta carotene compound by spectrophotometer method at absorbance $445 \mathrm{~nm}$. The results showed that strands of yellow pumpkin fruit contain beta carotene. In the extraction with Petroleum Ether (EPE), the beta-carotene content of EPE-strands $39.1 \mu \mathrm{g} / \mathrm{g}$, ethanol extract (EET) of strands pumpkin flour, yielded $7.94 \mu \mathrm{g} / g$ of beta carotene. The highest beta carotene content of the two extraction types EEP and EET are found in the extract with Petroleum Ether (EPE) because Petroleum Eter is a non-polar solvent which can dissolve less polar compounds that reside on cell walls such as terpenoids. Pumpkin fruit extract can be used as food fortification to increase the nutritional value.
\end{abstract}

\section{A BSTRAK}

Tujuan penelitian ini adalah untuk mengidentifikasi senyawa karetenoid seperti beta karoten, dari berbagai ekstrak jonjot buah labu kuning. Tanaman labu sebagai komoditas pangan minor, ternyata sangat kaya dengan senyawa bioaktif yang berperan sebagai antiokisidan yang sangat berguna bagi kesehatan manusia. Jonjot dalam pengolahan buah labuh kuning sering dijadikan limbah. Penelitian ini dilaksanakan dengan menggunakan metode analisis laboratorium melalui tahapan-tahapan sebagai berikut, penentuan dan pengambilan sampel, preparasi sampel, analisis kandungan senyawa beta karoten dengan metode spektrofotometer pada absorbansi $445 \mathrm{~nm}$. Hasil penelitian menunjukkan bahwa jonjot dari buah labu kuning memiliki kandungan beta karoten. Pada ekstraksi dengan Petroleum Eter (EPE) diperoleh kadar beta karoten sebagai berikut EPE-jonjot $39.1 \mu \mathrm{g} / \mathrm{g}$, Ekstrak Etanol (EET) tepung jonjot labu kuning, menghasilkan beta karoten sebesar 7,94 $\mu \mathrm{g} / \mathrm{g}$. Kandungan beta karoten tertinggi dari dua jenis ekstraksi yakni EEP dan EET, terdapat pada ekstrak dengan Petroleum Eter (EPE) hal ini disebabkan oleh karena Petroleum Eter merupakan pelarut non polar yang dapat melarutkan senyawa-senyawa yang bersifat kurang polar yang berada pada dinding sel seperti terpenoid. Ekstrak buah labu dapat dijadikan sebagai bahan fortifikasi pangan untuk meningkatkan nilai gizi. 


\section{Pendahuluan}

Labu kuning atau waluh (Cucurbita moschata), termasuk dalam komoditas pangan yang pemanfaatannya masih sangat terbatas. Banyak bahan pangan lokal Indonesia yang mempunyai potensi gizi dan komponen bioaktif yang baik, namun belum termanfaatkan secara optimum [1]. Tanaman labu kuning sebagai komoditas pangan minor, ternyata sangat kaya dengan senyawa bioaktif yang sangat berguna bagi kesehatan manusia, namun penelitian tentang karakterisasi dan potensi pemanfaatan komoditas pangan minor masih sangat sedikit dibandingkan komoditas pangan utama, seperti padi dan kedelai.

Jonjot buah labu kuning mengandung senyawa karotenoid misalnya senyawa beta karoten yang dapat berperan sebagai anti oksidan yang dapat menghambat proses oksidasi didalam tubuh manusia. Beta karoten sendiri sesungguhnya merupakan provitamin A yakni sumber penting bagi vitamin A di dalam saluran pencernaan khususnya pada usus halus, beta karoten akan mengalami penyerapan yang kemudian di simpan di dalam sel hati. Di dalam sel hati, beta karoten akan diubah menjadi vitamin A dan siap digunakan kalau dibutuhkan untuk berbagai reaksi metabolisme [2]. Berdasarkan uraian diatas menunjukan bahwa jonjot labu kuning memiliki potensi yang sangat besar sebagai sumber senyawa yang berperan sebagai antioksidan alami seperti senyawa beta karoten, namun belum banyak data yang tersedia untuk menggali potensi antioksidan, bahkan jonjot dalam pengolahan bahan makanan dari labuh kuning sering dijadikan limbah. sehingga sangatlah menarik untuk dilakukan penelitian agar dapat diperoleh informasi ilmiah yang berhubungan dengan kandungan senyawa karotenoid jonjot buah labu kuning. Penelitian ini bertujuan untuk menentukan kandungan beta karoten jonjot buah labu kuning.

\section{Bahan dan Metode}

Bahan utama yang digunakan dalam penelitian ini adalah buah labu kuning umur panen 3-4 bulan, yang diperoleh dari Daerah Modoinding Minahasa Selatan Propinsi Sulawesi Utara. Bagian buah yang digunakan untuk penelitian ini adalah kulit, daging, jonjot, dan biji. Bahan kimia yang digunakan adalah petroleum eter, etanol, natrium hidroksida, asam sulfat, natrium karbonat, reagen Folin Ciocalteu, dan larutan 1,1-diphenil-2-picryhidrasil dan eritrosin.

\section{Preparasi Sampel}

Buah labu kuning dibersihkan/dicuci dengan air, selanjutnya dipisahkan jonjot buah kuning. Jonjot yang sudah dipisahkan kemudian dikeringkan dengan oven pada suhu $60-70{ }^{\circ} \mathrm{C}$, setelah kering dihaluskan dengan menggunakan blender, selanjutnya diayak sampai diperoleh partikel dengan ukuran 60 mesh dan diperoleh tepung labu kuning.

\section{Ekstraksi Karotenoid}

Sampel yang telah dihaluskan ditambah dengan $\mathrm{CaCO}_{3}$, diekstrasi dengan menggunakan pelarut petroleum eter (PE) dan etanol (ET), ekstrak pigmen yang diperoleh disaring, dan residunya diekstraksi kembali dengan pelarut baru. Ekstrak pigmen dipekatkan dengan menggunakan rotary evaporator dan kemudian dikeringkan dengan oven dihasilkan ekstrak pigmen kering. Kandungan total karotenoid diukur dengan menggunakan metode Gross [3].

\section{Hasil dan Pembahasan}

\section{Kandungan Karotenoid Dan Beta Karoten}

Kandungan total karotenoid diukur dengan menggunakan metode Gross [3]. Perbandingan hasil pengujian kandungan total karotenoid pada bagian buah labu kuning dapat dilihat pada Tabel 1.

Data dalam Tabel 1, menunjukkan bahwa kandungan total karotenoid tertinggi terdapat pada Ekstrak Jonjot dengan Petroleum Eter yakni 78,2 $\mu \mathrm{g} / \mathrm{g}$, hal ini disebabkan oleh karena Petroleum Eter merupakan pelarut non polar yang dapat melarutkan senyawa-senyawa yang bersifat kurang polar yang berada pada dinding sel seperti terpenoid.

Peran penting karotenoid adalah sebagai agen antioksidan dalam sistem fotosintesis. Kandungan beta karoten diperoleh melalui ekuivalen dari karotenoid. Kemampuan beta karoten untuk menginaktifkan radikal bebas bukan karena dapat berubah menjadi Provitamin A, tetapi karena adanya ikatan rangkap yang banyak pada struktur molekul. 
Tabel 1. Perbandingan Kadar Karotenoid dan Beta Karoten Labu Kuning Dalam berbagai Ekstrak

\begin{tabular}{|c|c|c|c|c|c|c|}
\hline \multirow[t]{3}{*}{ Bagian Buah } & \multicolumn{6}{|c|}{$\begin{array}{c}\text { Kadar Karotenoid dan Beta Karoten } \\
\mu \mathrm{g} / \mathrm{g}\end{array}$} \\
\hline & \multicolumn{3}{|c|}{ EPE } & \multicolumn{3}{|c|}{ EET } \\
\hline & Ulangan & $\begin{array}{c}\text { Total } \\
\text { Karoten }\end{array}$ & Beta Karoten & Ulangan & $\begin{array}{c}\text { Total } \\
\text { Karoten }\end{array}$ & Beta Karoten \\
\hline Jonjot & $\begin{array}{l}78.24 \\
78.16\end{array}$ & $78.2 \pm 0.04$ & $39,1 \pm 0.02$ & $\begin{array}{l}15.48 \\
15.92\end{array}$ & $15,88 \pm 0.22$ & $7,94 \pm 0.11$ \\
\hline
\end{tabular}

Beta karoten menangkap radikal peroksil di dalam jaringan pada tekanan parsial oksigen yang rendah [4]. Reaksi beta karoten dengan radikal bebas akan diperoleh radikal bebas dari beta karoten yang relatif lebih stabil dan tidak memiliki energi yang cukup untuk dapat bereaksi dengan molekul lain membentuk radikal baru $[3,5]$.

\section{Kesimpulan}

Ekstrak Petroleum Eter (EPE) tepung jonjot labu kuning, menghasilkan beta karoten sebesar 39,1 $\mu \mathrm{g} / \mathrm{g}$. Ekstrak Etanol (EET) tepung jonjot labu kuning, menghasilkan beta karoten sebesar 7,94 $\mu \mathrm{g} / \mathrm{g}$.

Kandungan beta karoten tertinggi dari dua jenis ekstraksi, terdapat pada ekstrak dengan Petroleum Eter (EPE) hal ini disebabkan oleh karena Petroleum Eter merupakan pelarut non polar yang dapat melarutkan senyawa-senyawa yang bersifat kurang polar yang berada pada dinding sel seperti terpenoid.

\section{Daftar Pustaka}

1. Hendrasty, H. K. Tepung Labu Kuning Pembuatan dan Pemanfaatannya; Kanisius: Yogyakarta, 2003;

2. Astawan, M. Labu kuning penawar racun dan cacing pita yang kaya antioksidan; IPB Bogor, 2004;

3. Britton, G. Structure and properties of carotenoids in relation to function. FASEB J. 1995, 9, 1551-1558.

4. Lautan, J. Radikal bebas pada eritrosit dan leukosit. Cermin Dunia Kedokt. 1997, 116, 49-52.

5. Gordon, M. H. The Mechanism of Antioxidant Action in Vitro. In Food Antioxidants; Elsevier Applied Food Science Series; Springer, Dordrecht, 1990; pp. 1-18 ISBN 978-94-010-6824-6. 